\title{
KINERJA PEMASARAN \\ PADA UKM MEBEL DI KABUPATEN KUNINGAN
}

\author{
Oleh: \\ Iskandar*; Putri Y. A.**; Micita Sani**; Siti Hamidah**; dan Riki Irawan**
}

\begin{abstract}
Abstrak
Masalah yang ingin diteliti dalam penelitian ini adalah menurunnya kinerja pemasaran perusahaan-perusahaan UKM Mebel di Kabupaten Kuningan. Untuk bisa mengatasi masalah ini, maka perlu diketahui faktor-faktor penyebabnya. Telaah pustaka menunjukkan bahwa kinerja pemasaran ini dipengaruhi secara langsung oleh keunggulan bersaing. Sementara keunggulan bersaing dipengaruhi oleh perilaku kewirausahaan, adaptabilitas lingkungan, kualitas aset stratejik, dan orientasi pasar. Oleh karena itu, penelitian ini ingin menguji keterkaitan kelima variabel tersebut, untuk kemudian mencari solusi bagi permasalahan penurunan kinerja pemasaran di atas. Penelitian dilakukan terhadap 82 perusahaan sebagai sampel terpilih dari populasi sejumlah 103 perusahaan. Data diperoleh dari angket yang telah teruji validitas dan reliabilitasnya, yang kemudian dianalisis dengan menggunakan path analysis. Hasil penelitian menunjukkan bahwa lemahnya keunggulan bersaing merupakan faktor utama yang menyebabkan menurunnya kinerja pemasaran perusahaan-perusahaan mebel di Kabupaten Kuningan. Sementara itu, lemahnya keunggulan bersaing disebabkan oleh lemahnya adaptabilitas lingkungan, orientasi pasar, kualitas aset stratejik, dan perilaku kewirausahaan mereka. Berdasarkan temuan penelitian ini, maka untuk meningkatkan kinerja pemasaran mereka direkomendasikan untuk: meningkatkan inovasi produk sehinga tidak kalah oleh pesaing, pantau dan perhatikan produk pesaing, sering-seringlah ikut pameran untuk menambah wawasan dan mengasah kreativitas, perbaiki hubungan dengan penyalur, ikutilah pelatihanpelatihan marketing, serta perluas jejaring untuk meningkatkan kapabilitas organisasi. Kata Kunci : Kinerja Pemasaran, Keunggulan Bersaing, adaptabilitas lingkungan, orientasi pasar, kualitas aset stratejik, dan perilaku kewirausahaan.
\end{abstract}

\section{Pendahuluan}

Dalam kurun waktu 5 (lima) tahun terakhir UKM Mebel di Kabupaten Kuningan mengalami penurunan kinerja pemasaran yang ditandai dengan menurunnya omset penjualan. Dari hasil penjualan perusahaan-perusahaan mebel yang tercatat di Dinas Perindustrian Kabupaten Kuningan, antara tahun 2012 sd tahun 2016, penurunan omset penjualan ini mencapai 31,47 \%. Ini merupakan masalah yang cukup serius, karena bisa mengancam keberlangsungan usaha.
Oleh karena itu, harus segera dicari solusinya.

Untuk mendapatkan solusi yang memadai, maka harus terlebih dahulu diidentifikasi faktor-faktor apa yang menyebabkan menurunnya kinerja pemasaran tersebut. Telaah teori dan hasil-hasil penelitian sebelumnya, menunjukkan bahwa kinerja pemasaran dipengaruhi oleh faktor-faktor internal dan faktor-faktor eksternal dari perusahaan. Dari sisi internal, kinerja pemasaran sangat ditentukan oleh efektivitas organisasi khususnya dalam menciptakan keunggulan bersaing 
(Porter, 1994; Cravens, 1999). Sementara itu, faktor penentu keunggulan bersaing, lebih ke persoalan yang terjadi dalam perusahaan tersebut, seperti kualitas aset stratejik (Ferdinand, 2003), adaptabilitas lingkungan (Hunger dan Thomas, 2003 dalam Barokah, 2009), orientasi pasar ( Narver dan Slater, 1990 dalam Tjiptono dan Chandra, 2012), dan perilaku kewirausahaan ( Alma, 2008; Suryana, 2006).

\section{Perumusan Masalah}

Berangkat dari latar belakang di atas, maka masalah penelitian ini dapat dirumuskan sebagai berikut:

a. Apakah penurunan kinerja pemasaran perusahaanperusahaan UKM Mebel di Kabupaten Kuningan dipengaruhi secara positif oleh faktor keunggulan bersaing mereka?

b. Apakah keunggulan bersaing perusahaan dipengaruhi secara positif oleh faktor-faktor pembentuknya, seperti perilaku kewirausahaan, adaptabilitas lingkungan, kualitas aset strategis, dan orientasi pasar?

c. Apakah faktor-faktor perilaku kewirausahaan, adaptabilitas lingkungan, kualitas aset strategis, dan orientasi pasar juga berpengaruh secara langsung terhadap kinerja pemasaran?

\section{Manfaat Hasil Penelitian}

Secara teoritis, hasil penelitian ini diharapkan dapat menambah data empirik yang dapat memperkaya teoriteori yang berkenaan dengan variabelvariabel: kinerja pemasaran, keunggulan bersaing, perilaku kewirausahaan, adaptabilitas lingkungan, kualitas aset stratejik, dan orientasi pasar.
Secara praktis, hasil penelitian ini diharapkan bisa memberikan solusi atas menurunnya kinerja pemasaran perusahaan-perusahaan UKM Mebel di Kabupaten Kuningan.

\section{Kerangka Berfikir dan Hipotesis}

Kinerja pemasaran, pada dasarnya, merupakan ukuran prestasi yang diperoleh dari aktivitas proses pemasaran secara menyeluruh dari sebuah perusahaan atau organisasi (Kotler, 2005; Potter, 1994; Ferdinand, 2003). Kinerja pemasaran sangat penting untuk diketahui perusahan karena dapat mengukur prestasi pasar suatu produk dan mengevaluasi efektivitas strategi pemasaran yang digunakan (Ferdinand, 2003).

Terdapat banyak faktor yang bisa mempengaruhi kinerja pemasaranan suatu perusahaan, baik faktor internal maupun faktor eksternal. Cravens (1999) menyatakan bahwa kinerja pemasaran suatu perusahaan sangat ditentukan oleh efektivitas organisasi, khususnya dalam menciptakan keunggulan bersaing terhadap para pesaingnya.

Hipotesis 1: Kinerja pemasaran dipengaruhi secara positif oleh keunggulan bersaing.

Keunggulan bersaing merupakan keunggulan yang dimiliki perusahaan dalam hal menawarkan nilai dan harga kepada konsumen dibanding penawaran pesaing (Kotler dan Amstrong, 2008; Porter,1994; Coulter dalam Kuncoro, 2006). Menurut Porter (1994:20), faktor penentu keunggulan bersaing suatu perusahaan adalah : a) Faktor-faktor kondisi perusahaan, seperti kualitas tenaga kerja, kualitas infrastruktur, kualitas produk, kualitas aset, kualitas manajemen, kualitas strategi perusahaan; b) Kondisi permintaan, seperti komposisi permintaan pasar, 
ukuran dan pertumbuhan pasar; dan c) Keberadaan industri terkait dan industri penunjang, seperti keberadaan dan kualitas industri penunjang dan hubungan antara industri lokal dalam koordinasi dan pembagian aktivitas dalam rantai nilai.

Mengingat faktor permintaan dan industri terkait berada di luar kontrol perusahaan, maka dalam penelitian ini hanya akan mendeteksi kondisi internal perusahaan meliputi variabel-variabel yang menurut para ahli dapat mempengaruhi keunggulan bersaing suatu perusahaan yaitu:

\section{1) Perilaku Kewirausahaan}

Kewirausahaan adalah

kemampuan kreatif dan inovatif yang dijadikan dasar, kiat, dan sumber daya untuk mencari peluang menuju sukses (Suryana, 2006:2). Dengan demikian maka perilaku kewirausahaan adalah perilaku kreatif dan inovatif yang dimiliki oleh seseorang yang dijadikan dasar dalam upaya mencapai kesuksesan. Sebuah perusahaan yang memiliki pimpinan dan karyawan yang kreatif dan inovatif bisa dipastikan akan menghasilkan produk yang berkualitas dan bisa bersaing di pasar. Oleh karena itu, sebagaimana disampaikan Porter (1994) di atas, pimpinan dan karyawan yang kreatif dan inovatif merupakan sumber keunggulan bersaing perusahaan.

Hipotesis 2: Perilaku kewirausahaan berpengaruh positif terhadap keunggulan bersaing.

2) Adaptabilitas Lingkungan

\begin{tabular}{lll}
\multicolumn{2}{c}{ Adaptabilitas } & lingkungan \\
adalah kemampuan & perusahaan \\
untuk membaca, & memahami
\end{tabular} lingkungan sosialnya (Kotler dan Amstrong, 2008). Menurut Pearce dan Robinson, 2007, dalam Barokah, 2009:43) adaptabilitas lingkungan memiliki tiga indikator, yaitu: 1) kemampuan memahami pelanggan, 2) kemampuan memahami pesaing, dan 3) kemampuan memahami saluran distribusi. Sebuah perusahaan yang memiliki adaptabilitas lingkungan yang baik tentu saja, sebagaimana pendapat Porter (1994) di atas, akan memiliki keunggulan terhadap para pesaingnya.

Hipotesis 3: Adaptabilitas lingkungan berpengaruh positif terhadap keunggulan bersaing.

3) Kualitas Aset Stratejik

Aset stratejik perusahaan adalah sumber daya dan kapabilitas yang bersifat langka, tahan lama, tidak mudah diperdagangkan, serta sulit ditiru yang dapat digunakan untuk mengkonversi value menjadi profit (Ferdinand, 2003). Aset stratejik ini biasanya dimiliki oleh perusahaan berupa nama merk, terobosan teknologi, ikatan-ikatan jaringan kerja, tradisi-tradisi sosial perusahaan, praktek-praktek manajemen yang superior terhadap pelanggan. Dengan demikian jelas bahwa aset stratejik perusahaan yang berkualitas akan menjadi faktor penentu keunggulan bersaing persahaan.

Hipotesis 4: Kualitas aset stratejik berpengaruh positif terhadap keunggulan bersaing.

4) Orientasi Pasar

Orientasi pasar merupakan budaya bisnis dimana organisasi mempunyai komitmen untuk terus berkreasi dalam menciptakan nilai unggul bagi pelanggan (Narver dan Slater, 1990 dalam Meike S., 2009; Fandy Tjiptono dan Gregorius Chandra, 2012). Suatu perusahaan yang menekankan pada pentingnya perhatian terhadap pasar (berorientasi pasar) akan mengarah pada penguatan keunggulan bersaing 
perusahaan (Bharadwaj et al., 1993

dalam Meike S. 2009).

Hipotesis 5: Orientasi pasar berpengaruh positif terhadap keunggulan bersaing.

Telaah teori terhadap keempat variabel independen di atas, menunjukkan juga bahwa keempat variabel tersebut juga berpengaruh secara langsung terhadap kinerja pemasaran. Oleh karena itu, lahirlah hipotesis-hipotesis di bawah ini:

Hipotesis 6: Perilaku kewirausahaan berpengaruh positif terhadap kinerja pemasaran.
Hipotesis 7: Adaptabilitas lingkungan berpengaruh positif terhadap kinerja pemasaran.

Hipotesis 8: Kualitas aset stratejik berpengaruh positif terhadap kinerja pemasaran.

Hipotesis 9: Orientasi pasar berpengaruh positif terhadap kinerja pemasaran.

Berdasarkan kerangka berfikir yang menghasilkan hipotesis-hipotesis di atas, maka model penelitian ini dapat digambarkan dalam bentuk diagram alur sebagai berikut:

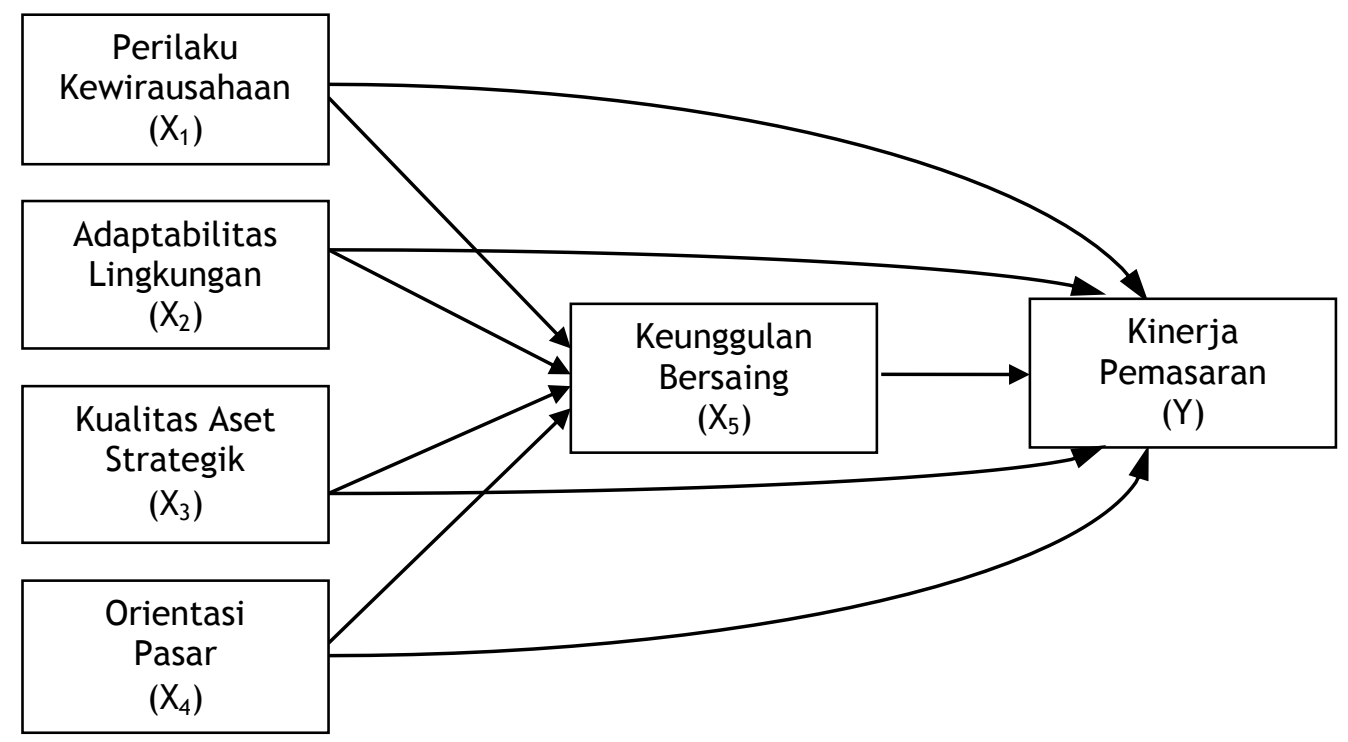

Gambar 1: Model Penelitian

\section{Metode Penelitian}

Penelitian ini termasuk jenis penelitian korelasional, yaitu penelitian yang ingin menguji hubungan-hubungan antar variabel dengan tujuan untuk membuat prediksi berdasarkan derajat korelasi antar variabel tersebut (Nur Indriantoro dan Bambang Supomo, 1999). Metode yang digunakan adalah survey, yaitu suatu metode penelitian yang ditujukan pada sejumlah besar individu atau kelompok dengan fokus pada beberapa variabel saja (Sanapiah Faisal, 1989).

Data penelitian dikumpulkan melalui kuesioner (angket) yang diisi oleh pemilik atau pimpinan UKM mebel. Angket disusun secara hati-hati berdasarkan indikator-indikator yang dirujuk dari teori. Sebelum disebarkan pada responden semua angket telah teruji validitas dan reliabilitasnya.

Adapun indikator-indikator yang dijadikan dasar dalam penyusunan instrumen adalah sebagai berikut: 1) 
Indikator kinerja pemasaran, yaitu: a) omset penjualan; b) peningkatan penjualan; c) sales return; dan d) jangkauan wilayah pemasaran (Ferdinand, 2003); 2) Indikator keunggulan bersaing, yaitu: a) unik; b) harga bersaing; c) jarang dijumpai; d) tidak mudah ditiru; dan e) tidak mudah diganti (Bharadwaj et al. dalam Meike, 2009:29); 3) Indikator perilaku kewirausahaan, yaitu: a) pantang menyerah; b) memiliki pandangan kedepan; c) kreativitas; d) cemerlang; e) ulet; f) sosialis atau dapat bergaul; dan g) mampu berkompetisi/bersaing (Buchari Alma (2008:49); 4) Indikator adaptabilitas lingkungan, yaitu : a) kemampuan memahami pelanggan; b) kemampuan memahami pesaing; c) kemampuan bekerjasama dengan penyalur (Hunger dan Thomas, 2003 dalam Barokah, (2009:42); 5) Indikator kualitas asset stratejik, yaitu: a) sumber daya manusia; b) manajemen pengetahuan; c) kapabilitas organisasi; dan d) pengalaman (Nonaka \& Takeuchi, 1996 dalam Barokah, 2009:43); dan 6) Indikator orientasi pasar, yaitu : a) orientasi pelanggan; b) orientasi pesaing; dan c) informasi pasar (Narver dan Slater, 1990 dalam Mieke Supranoto, 2009:32).
Populasi penelitian adalah seluruh UKM Mebel yang ada di Kabupaten Kuningan yang berjumlah 103 perusahaan. Berdasarkan omset penjualannya, populasi dikelompokkan menjadi empat kategori. Jumlah sampel diperoleh berdasarkan rumus Slovin dengan tingkat kepercayaan 95\% $(e=0,05)$, yaitu 82 perusahaan. Teknik sampling yang digunakan adalah Propotional Stratified Random Sampling.

Sebelum dianalisis, data penelitian diuji dulu normalitas dan multikolinieritasnya sehingga memenuhi persyaratan penggunaan statistik parametrik. Karena model penelitian menunjukkan adanya pengaruh langsung dan tidak langsung maka analisis data menggunakan path analysis dengan pendekatan regresi (Riduwan dan Kuncoro, 2007). Hipotesis diuji dengan menggunakan uji-t.

\section{Hasil Penelitian dan Pembahasan}

\section{1) Hasil Penelitian}

Sub struktur 1 menguji pengaruh variabel X1, X2, X3, dan X4 terhadap $\mathrm{X} 5$, diperoleh hasil yang bisa dibaca pada tabel 1di bawah ini:

Tabel 1

Hasil Perhitungan Uji Hipotesis

Coefficients $^{a}$

\begin{tabular}{|c|c|c|c|c|c|c|}
\hline \multirow[t]{2}{*}{ Mod } & & \multicolumn{2}{|c|}{$\begin{array}{l}\text { Unstandardized } \\
\text { Coefficients }\end{array}$} & \multirow{2}{*}{$\begin{array}{c}\text { Standardized } \\
\text { Coefficients } \\
\text { Beta }\end{array}$} & \multirow[t]{2}{*}{$\mathrm{t}$} & \multirow[t]{2}{*}{ Sig. } \\
\hline & & $\mathrm{B}$ & Std. Error & & & \\
\hline \multirow{5}{*}{1} & (Constant) & 1,953 & 2,387 & & 3,182 & ,042 \\
\hline & Perilaku Kewirausahaan & ,515 & ,064 & ,554 & 8,059 & ,000 \\
\hline & Adaptabilitas Lingkungan & ,449 & ,284 & ,504 & 5,581 & ,012 \\
\hline & Kualitas Asset Stratejik & ,901 & , 148 & ,424 & 4,000 & 020 \\
\hline & Orientasi Pasar & 1,054 & ,331 & ,390 & 3,186 & ,002 \\
\hline
\end{tabular}

a. Dependent Variable: Keunggulan Bersaing 
Berdasarkan tabel 1 di atas, terlihat bahwa nilai probabilitas (sig) semuanya menunjukkan angka di bawah 0,05. Hal ini berarti bahwa hipotesis 2, 3, 4, dan 5 dapat diterima secara statistik.

Dengan demikian diperoleh diagram jalur model sub struktur 1 sebagai berikut :

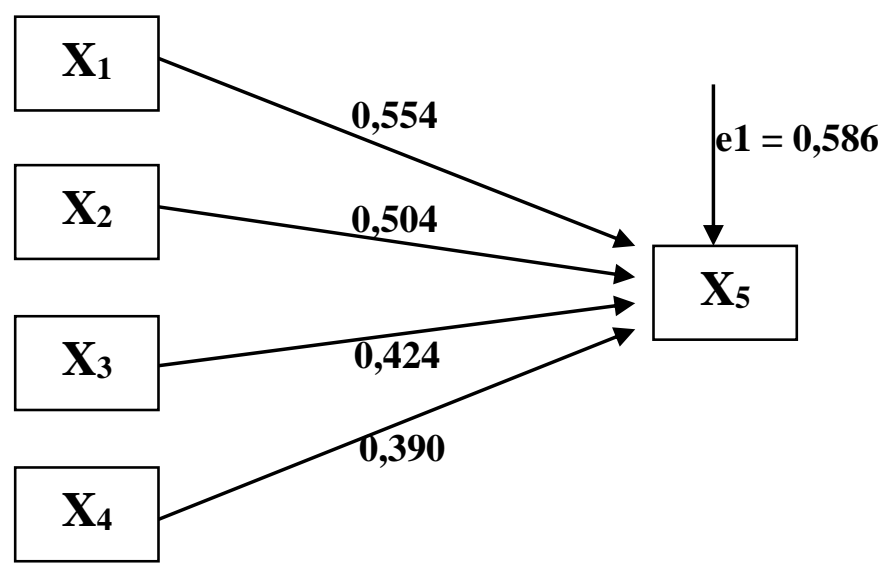

Gambar 2: Diagram Jalur Model Sub Struktur 1

Sub struktur 2 menguji pengaruh variabel $\mathrm{X} 1, \mathrm{X} 2, \mathrm{X} 3, \mathrm{X} 4$, dan X5 terhadap Y, diperoleh hasil sebagai berikut:

Tabel 2

Hasil Perhitungan Uji Hipotesis

Coefficients $^{\mathrm{a}}$

\begin{tabular}{|l|r|r|r|r|r|}
\hline \multirow{2}{*}{ Model } & \multicolumn{3}{|c|}{$\begin{array}{c}\text { Unstandardized } \\
\text { Coefficients }\end{array}$} & $\begin{array}{c}\text { Standardized } \\
\text { Coefficients }\end{array}$ & \multicolumn{1}{c|}{ Sig. } \\
\cline { 2 - 4 } & \multicolumn{1}{|c|}{ B } & Std. Error & \multicolumn{1}{c|}{ Beta } & & \\
\hline (Constant) & 5,132 & 2,334 & & 2,198 &, 031 \\
Perilaku Kewirausahaan & 2,024 &, 085 &, 255 & 3,279 &, 035 \\
Adaptabilitas Lingkungan &, 435 &, 281 &, 490 & 4,546 &, 013 \\
Kualitas Asset Stratejik &, 457 &, 145 &, 319 & 3,400 &, 032 \\
Orientasi Pasar &, 411 &, 343 &, 467 & 4,199 &, 023 \\
Keunggulan Bersaing &, 710 &, 111 &, 714 & 6,394 &, 000 \\
\hline
\end{tabular}

a. Dependent Variable: Kinerja Pemasaran

Seperti pada pengujian sub struktur 1 , berdasarkan tabel 2 di atas terlihat bahwa nilai probabilitas (sig) semuanya menunjukkan angka di bawah 0,05 . Hal ini berarti bahwa hipotesis $1,6,7,8$, dan 9 dapat diterima secara statistik.

Dengan demikian diperoleh diagram jalur model sub struktur 2 sebagai berikut: 


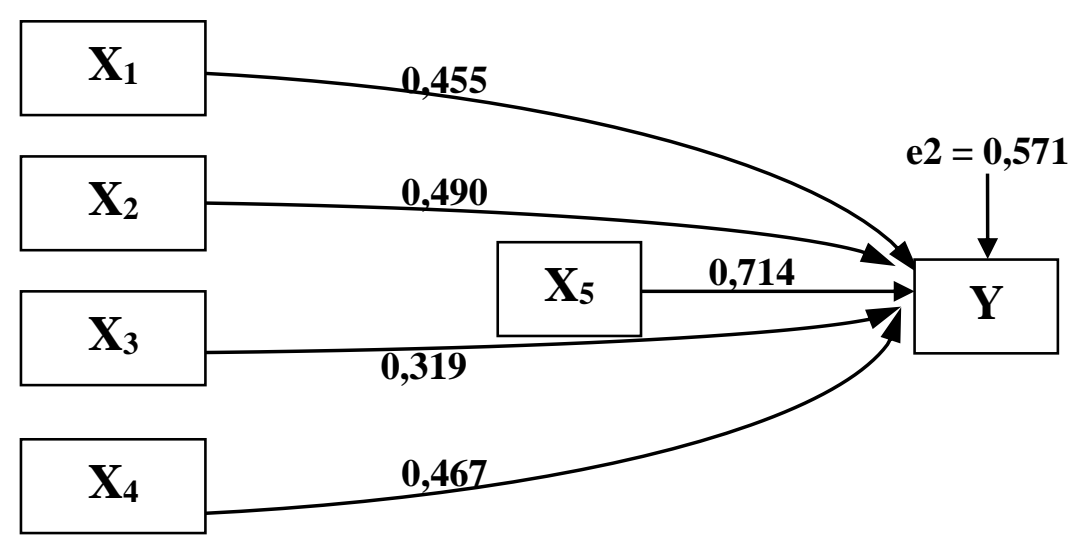

Gambar 3: Diagram Jalur Model Sub Struktur 2

Dengan demikian diperoleh diagram jalur lengkap sebagai berikut :

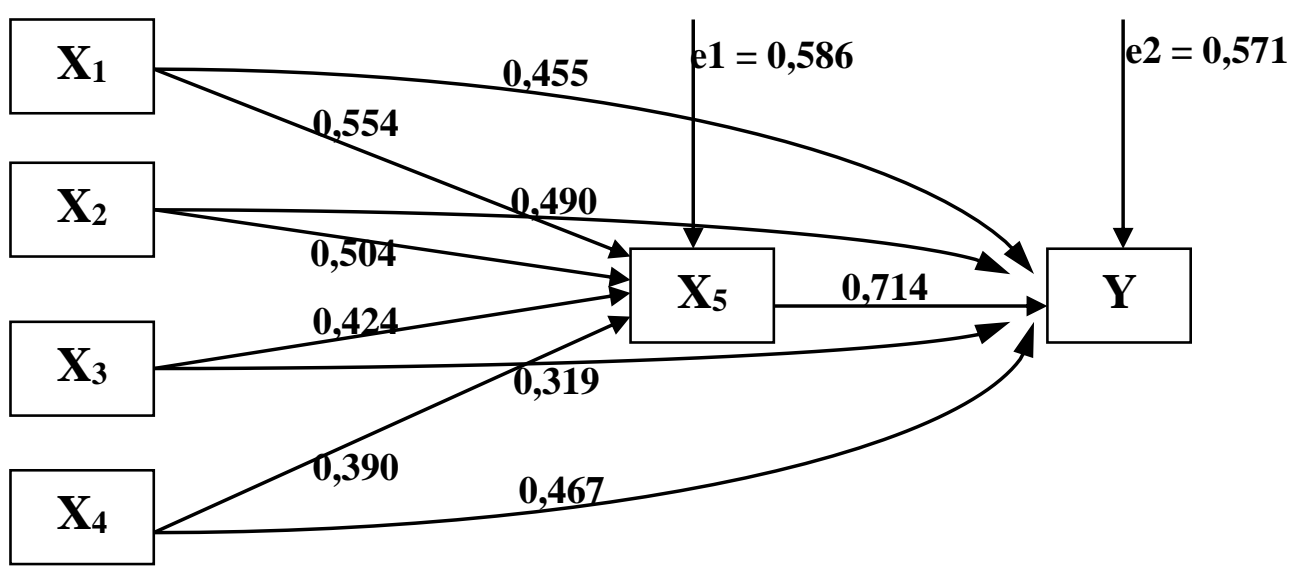

Gambar 4: Diagram Jalur Lengkap

Berdasarkan hasil variabel untuk menghitung pengujian hipotesis penelitian pengaruh totalnya, sebagai tersebut dapat dihitung dekomposisi pengaruh antar berikut:

Tabel 3

Dekomposisi Pengaruh Antar Variabel

\begin{tabular}{|c|c|c|c|c|}
\hline No. & Variabel & $\begin{array}{c}\text { Pengaruh } \\
\text { Langsung }\end{array}$ & $\begin{array}{c}\text { Pengaruh Tidak } \\
\text { Langsung }\end{array}$ & $\begin{array}{c}\text { Total } \\
\text { Pengaruh }\end{array}$ \\
\hline 1 & $\mathrm{X} 1$-> X5 & 0,554 & - & 0,554 \\
\hline 2 & $\mathrm{X} 2$-> X5 & 0,504 & - & 0,504 \\
\hline 3 & $\mathrm{X} 3$-> X5 & 0,424 & - & 0,424 \\
\hline 4 & $\mathrm{X} 4$-> X5 & 0,390 & - & 0,390 \\
\hline 5 & $\mathrm{X} 5$-> Y & 0,714 & - & 0,714 \\
\hline 6 & $\mathrm{X} 1$-> X5 -> Y & 0,455 & 0,395 & 0,850 \\
\hline
\end{tabular}




\begin{tabular}{|l|l|l|l|l|}
\hline 7 & $X 2$-> X5 -> Y & 0,490 & 0,360 & 0,850 \\
\hline 8 & $X 3$-> X5 -> Y & 0,319 & 0,302 & 0,621 \\
\hline 9 & $X 4$-> X5 -> Y & 0,467 & 0,278 & 0,745 \\
\hline
\end{tabular}

2) Pembahasan

Hasil analisis data sebagaimana dapat dibaca pada gambar 4 dan tabel 3 di atas menunjukkan bahwa faktor utama yang menyebabkan menurunnya kinerja pemasaran perusahaanperusahaan UKM Mebel di Kabupaten Kuningan adalah lemahnya keunggulan bersaing mereka (koefisien beta 0,714). Dengan kata lain, mereka kalah bersaing dari perusahaan sejenis dari daerah lain. Di antara lima indikator dari keunggulan bersaing, hanya satu yang skornya relatif tinggi, yaitu harga bersaing. Sementara keempat indikator lainnya, yaitu: unik, jarang dijumpai, tidak mudah ditiru, dan tidak mudah diganti semuanya memperoleh skor rendah.

Hasil ini menguatkan pendapat para ahli yang menekankan tentang pentingnya competitive advantage dalam menghadapi persaingan. Porter (1994:3) misalnya menyatakan bahwa, "Keunggulan bersaing (competitive advantage) adalah jantung kinerja bisnis untuk menghadapi persaingan". Chaiman General Electric, Jack Welch (Sherman, 1989: 50) menekankan tentang kenyataan keunggulan bersaing. "Jika kamu tidak punya keunggulan bersaing, jangan bersaing". Para ahli setuju bahwa terdapat hubungan yang kuat antara keberhasilan bisnis dan keunggulan bersaing (Cravens, 1999:31).

Selain dipengaruhi keunggulan bersaing, kinerja pemasaran UKM Mebel di Kabupaten Kuningan juga dipengaruhi secara langsung oleh perilaku kewirausahaan $(0,455)$; adaptabilitas lingkungan $(0,490)$; kualitas aset stratejik $(0,319)$; dan orientasi pasar $(0,467)$. Artinya, kinerja pemasaran dipengaruhi pula oleh variabel-variabel pembentuk variabel keunggulan bersaing. Hasil ini sejalan dengan penelitianpenelitian sebelumnya di tanah air yang dilakukan antara lain oleh Meike Supranoto, (2009), Siti Nur Barakah (2009), Dewi Fadmawati Kadek (2011), Soviadi Nor Rachman (2006), Astrid Orsini Depary (2010), Tribuana Dewi Sensi (2005) dan Adi Sismanto (2006).

Sementara itu, keunggulan bersaing dipengaruhi secara positif oleh perilaku kewirausahaan $(0,554)$, adaptabilitas lingkungan $(0,504)$, kualitas aset stratejik $(0,424)$, dan orientasi pasar $(0,390)$. Artinya, lemahnya keunggulan bersaing perusahaan UKM mebel di Kabupaten Kuningan disebabkan oleh lemahnya perilaku kewirausahaan mereka, lemahnya adaptabilitas lingkungan mereka, lemahnya kualitas aset stratejik mereka, serta lemahnya orientasi pasar mereka. Apabila kita cermati angkanya, terlihat bahwa faktor yang paling mempengaruhi keunggulan bersaing perusahaan mebel Kabupaten Kuningan adalah perilaku kewirausahaan mereka yang cenderung belum optimal. Kemudian kemampuan untuk beradaptasi dengan lingkungan, kualitas aset stratejik, dan orientasi pasar. Oleh karena itu, upaya untuk meningkatkan keunggulan bersaing 
perusahaan mebel di Kabupaten Kuningan harus dimulai dari pembenahan kondisi dari variabelvariabel tersebut.

\section{Kesimpulan dan Rekomendasi}

1) Kesimpulan

a) Menurunnya kinerja pemasaran perusahaan mebel di Kabupaten Kuningan terutama disebabkan oleh lemahnya kemampuan bersaing mereka. Dari lima indikator keunggulan bersaing yang diobservasi, hanya harga yang mendapat nilai cukup tinggi. Sementara keempat indikator lain, yaitu unik, jarang dijumpai, tidak mudah ditiru, dan tidak mudah diganti, semuanya lemah.

b) Keunggulan bersaing mereka lemah dikarenakan mereka lemah dalam perilaku kewirausahaannya, adaptabilitas lingkungannya, kualitas aset stratejiknya, dan orientasi pasarnya. Faktor yang paling mempengaruhi keunggulan bersaing perusahaan mebel Kabupaten Kuningan adalah perilaku kewirausahaan mereka yang cenderung belum optimal. Kemudian diikuti berturut-turut oleh kemampuan untuk beradaptasi dengan lingkungan, kualitas aset stratejik, dan orientasi pasar.

c) Perilaku kewirausahaan, adatabilitas lingkungan, kualitas aset stratejik, dan orientasi pasar juga mempunyai pengaruh potif secara langsung terhadap kinerja pemasaran.

2) Rekomendasi

Berangkat dari data deskriptif, berikut beberapa saran untuk memerbaiki kinerja pemasaran perusahaan-perusahaan mebel di Kabupaten Kuningan:
Hasil ini mengkonfirmasi teoriteori dan penelitian-penelitian sebelumnya yang dijadikan rujukan dalam penelitian ini.

a) Perusahaan-perusahaan UKM mebel di Kabupaten Kuningan harus melakukan inovasi terhadap produk mereka. Hal ini karena produk mereka tidak memiliki keunikan, banyak ditemukan produk sejenis di pasar, mudah ditiru, dan gampang diganti oleh produk subtitusi. Dengan kata lain, produk mereka kalah bersaing dibanding produk pesaing.

b) Saran di atas, sesuai juga dengan temuan lain bahwa mereka kurang berorientasi pada pesaing sehingga sering kalah langkah dibanding pesaing.

c) Titik lemah lain yang harus diperbaiki oleh para pelaku UKM mebel di Kabupaten Kuningan adalah meningkatkan perilku kewirausahaan mereka, khususnya masalah kreativitas, dan pandangan ke depan. Mereka harus sering mengikuti atau melihat pameran-pameran produk sejenis yang sat ini sudah berkembang sangat maju. Sehingga mata mereka terbuka dan bisa memperbaiki diri.

d) Dalam hal adaptabilitas lingkungan, kelemahan mereka adalah kurang bagusnya kemampuan bekerjasama dengan penyalur. Hal ini harus diperbaiki karena penyalur adalah mata rantai penting kepada konsumen.

e) Temuan lain adalah kapabilitas organisasi dalam menghadai masalah modal, bahan baku, naiknya biaya produksi, dan strategi pemasaran masih lemah. Hal ini harus segera diperbaiki 
dengan cara memperluas jejaring dan mengikuti pelatihan- pelatihan marketing yang banyak diadakan.

\section{Daftar Pustaka}

Alma, Buchari (2008); Kewirausahaan, untuk Mahasiswa dan Umum; Bandung: Alfabeta.

Barokah, Siti Nur (2009); "Studi tentang Faktor-faktor yang Mempengaruhi Kualitas Strategi Bersaing untuk Meningkatkan Kinerja Perusahaan"; Thesis; Semarang: Universitas Diponegoro.

Cravens, David. W. (1999); Pemasaran Strategis Jilid I (terjemahan Lina Salim); Jakarta: Erlangga.

Depary, Astrid Orsini (2010); “Analisis Faktor-Faktor yang Mempengaruhi Kinerja Pemasaran di Stasiun Pengisian Bahan Bakar Untuk Umum (SPBU) Di Semarang"; Tesis; Program Magister Manajemen Pascasarjana Universitas Dipenogoro.

Faisal, Sanapiah (1989); Format-format Penelitian Sosial, Dasar-dasar dan Aplikasi; Jakarta: Rajawali.

Fatonah, Siti. 2009. “Pengaruh Bauran Pemasaran dan Orientasi Pasar Terhadap Keunggulan Bersaing Dalam Meningkatkan Kinerja Pemasaran Pada Perusahaan Batik di Surakarta". Jurnal Ilmu Ekonomi dan Manajemen Volume 6 nomor 1 hal 106. Universitas 17 Agustus: Surabaya.

Ferdinand, A.T. 2003. Manajemen Pemasaran: Sebuah Pendekatan Stratejik. Semarang: Badan Penerbit Universitas Diponegoro.

Indriantoro, Nur dan Bambang Supomo (1999); Metode Penelitian Bisnis, untuk Akuntansi dan Manajemen; Yogyakarta: BPFE.

Kadek, Dewi Fadmawati, (2011); "Reformulasi Strategi Pemasaran untuk Meningkatkan Occupancy Room Rate di Hotel Four Seasons Resort Jimbaran Bali"; Tesis; Denpasar: Universitas Udayana.

Kotler, Philip; (2005); Manajemen Pemasaran Jilid I (terjemahan Benyamiin Molan); Jakarta: Indeks.

Kotler dan Armstrong. 2006. Prinsip-prinsip Pemasaran jilid 1 edisi 12. Jakarta : Erlangga.

Kuncoro, Mudrajad (2006); Strategi Bagaimana Meraih Keunggulan Bersaing. Jakarta: Erlangga.

Porter, Michael E. (1994) Keunggulan Bersaing. Jakarta: Binarupa Aksara.

Rachman, Soviadi Nor (2006); “Analisis Pengaruh Keunggulan Produk, Reputasi Perusahaan Dan Asosiasi Merek Terhadap Kesuksesan Produk Baru Dalam Meningkatkan Kinerja Pemasaran. Studi Kasus pada Outlet Penjualan Produk Telkomflexi di Semarang"; Tesis; Program Magister Manajemen Pascasarjana Universitas Diponegoro.

Sensi, Tribuana Dewi (2005); Analisis Pengaruh Orientasi Bisnis dan Inovasi Produk Terhadap Keunggulan Bersaing Untuk Meningkatkan Kinerja Bisnis. Volume 3 No. 8. ISSN : 1967-9386. Diakses pada Februari 2015. Melalui World Wide Web: http://www.ipedr.com/vol11/25-R10037.pdf 
Sherman, Stratford P. (1989); “The Mind of Jack Welch” Fortune; 27 Maret 1989. Sismanto, Adi (2006); "Analisis Pengaruh Orientasi Pembelajaran, Orientasi Pasar dan Inovasi Terhadap Keunggulan Bersaing Untuk Meningkatkan Kinerja Pemasaran (Studi Empiris Pada Industri Kecil Dan Menengah Produk Makanan Di Provinsi Bengkulu)"; Tesis; Program Magister Manajemen Pascasarjana Unversitas Diponegoro.

Supranoto, Meike (2009); "Strategi Menciptakan Keunggulan Bersaing Produk Melalui Orientasi Pasar, Inovasi, Dan Orientasi Kewirausahaan Dalam Rangka Meningkatkan Kinerja Pemasaran (Studi Empiris Pada Industri Pakaian Jadi Skala Kecil Dan Menengah Di Kota Semarang"; Tesis; Semarang: Universitas Diponegoro.

Suryana (2006); Kewirausahaan, Pedoman Praktis: Kiat dan Proses Menuju Sukses; Jakarta: Salemba Empat.

Tjiptono, Fandy dan Gregorius Chandra (2012). Pemasaran Strategik. Yogyakarta: Andi. 